\title{
Global Water Governance and Climate Change: Identifying Innovative Arrangements for Adaptive Transformation
}

\author{
Maria de Lourdes Melo Zurita 1,* (D), Dana C. Thomsen 2,3,4, Neil J. Holbrook ${ }^{5}$ (D), Timothy F. Smith ${ }^{2,3,4}$, \\ Anna Lyth ${ }^{2}$, Paul G. Munro ${ }^{6}$, Annemarieke de Bruin ${ }^{7}$ (D), Giovanna Seddaiu ${ }^{8}$, Pier Paolo Roggero ${ }^{8}$ (D), \\ Julia Baird ${ }^{4}$, Ryan Plummer ${ }^{2,4,9}$, Ryan Bullock ${ }^{10}$, Kevin Collins ${ }^{11}$ and Neil Powell ${ }^{2,3}$ \\ 1 School of Geosciences, University of Sydney, Camperdown 2006, Australia \\ 2 Sustainability Research Centre, University of the Sunshine Coast, Sippy Downs 4556, Australia; \\ dthomsen@usc.edu.au (D.C.T.); tsmith5@usc.edu.au (T.F.S.); anna@red-sustainability.com.au (A.L.); \\ rplummer@brocku.ca (R.P.); npowell@usc.edu.au (N.P.) \\ 3 Swedish Centre for Education for Sustainable Development, Uppsala University, Carmegatan, \\ 362157 Visby, Sweden \\ 4 Environmental Sustainability Research Centre, Brock University, St. Catharines, ON L2S 3A1, Canada; \\ jbaird@brocku.ca \\ 5 Institute for Marine and Antarctic Studies, University of Tasmania, Battery Point 7004, Australia; \\ neil.holbrook@utas.edu.au \\ 6 School of Humanities and Languages, University of New South Wales, Kensington 2052, Australia; \\ paul.munro@unsw.edu.au \\ 7 Stockholm Environment Institute, University of York, York YO10 5NG, UK; annemarieke.debruin@york.ac.uk \\ 8 Desertification Research Centre and Department of Agricultural Sciences, University of Sassari, \\ viale Italia 39, 07100 Sassari, Italy; gseddaiu@uniss.it (G.S.); pproggero@uniss.it (P.P.R.) \\ 9 Stockholm Resilience Centre, Stockholm University, 10691 Stockholm, Sweden \\ 10 Department of Environmental Studies and Sciences, University of Winnipeg, Winnipeg, MB R3B 2E9, Canada; \\ r.bullock@uwinnipeg.ca \\ 11 Department of Engineering and Innovation, Open University, Walton Hall, Milton Keynes MK7 6AA, UK; \\ kevin.collins@open.ac.uk \\ * Correspondence: marilu.melo@sydney.edu.au; Tel.: +61-2-8627-6385
}

Received: 31 August 2017; Accepted: 21 December 2017; Published: 2 January 2018

\begin{abstract}
A convoluted network of different water governance systems exists around the world. Collectively, these systems provide insight into how to build sustainable regimes of water use and management. We argue that the challenge is not to make the system less convoluted, but rather to support positive and promising trends in governance, creating a vision for future environmental outcomes. In this paper, we analyse nine water case studies from around the world to help identify potential 'innovative arrangements' for addressing existing dilemmas. We argue that such arrangements can be used as a catalyst for crafting new global water governance futures. The nine case studies were selected for their diversity in terms of location, scale and water dilemma, and through an examination of their contexts, structures and processes we identify key themes to consider in the milieu of adaptive transformation. These themes include the importance of acknowledging socio-ecological entanglements, understanding the political dimensions of environmental dilemmas, the recognition of different constructions of the dillema, and the importance of democratized processes.
\end{abstract}

Keywords: adaptive transformation; global environmental governance; water governance; institutional analysis; innovative arrangements 


\section{Introduction}

The Anthropocene is predicted to compound the complexity of water issues around the world. The Intergovernmental Panel on Climate Change (IPCC) notes that anthropogenic climate change is increasing the intensity and variability of rainfall events and elevating water temperatures on a global scale [1]. These impacts are projected to affect global water availability and its quality by exacerbating many existing pollution and distribution issues [2]. Significant flow-on effects are also expected for issues concerning food security, biodiversity, economic security and human conflict [2-9]. Thus, as climate change impacts continue to affect access to, and the quality of, water, the need for innovative water governance structures becomes more pressing [10]. This is particularly relevant as current water management practices developed at local, regional and national scales may not adequately consider the impacts of climate change. Furthermore, this is compounded by potential limitations in relying on past hydrological experiences to secure waterscapes in the future [2,11,12]. In this context, water governance has become an increasingly salient global environmental issue $[13,14]$.

Water policy has tended to be approached in the context of a locality, country or catchment area; however, scientific debates have produced compelling arguments for adopting a global perspective on water management [15]. This has included an increased recognition that many problems with water management are more associated with governance failures than with resource-based issues (e.g., scarcity). As such, it has been argued that there is a need for a paradigm shift away from technocratic strategies of water management towards regimes that appreciate institutional complexities and human dimensions of water resources [16,17]. As Conca notes, a key issue with global water governance-and indeed global environmental governance in general- has been that international regimes have generally adopted an 'adjustment-around-the-edges view', shying away from approaches where the challenge is to develop new mechanisms for engaging socio-ecological controversies. The failure to push the world creatively towards more fundamental changes is a critical concern [13]. Compounding this challenge is the shift from government to governance, in that the governing position of nation-states is being increasingly shared with other actors such as non-governmental organisations (NGOs) and multi-lateral corporations [13,18,19]. Therefore, the nascent 'system' of global water governance has ultimately become quite a convoluted affair. The challenge, however, is not to make the system less messy; socio-ecological systems are complex, and as such messiness is an inevitable part of governing them [20-23]. Rather, there is a need to support positive and promising trends, 'creative' changes (in Conca's terminology), in governance and to work on creating constructive visions for future environmental outcomes [24].

In response to the above, we argue that 'innovative arrangements' for water governance can be found in the practices around existing water dilemmas. These can be mobilised as a starting point for crafting new water governance futures. There is thus a need to identify and support positive trends that are already underway to promote and enhance the current evolving system of global water governance [24]. The challenge then is finding ways to identify such configurations. The objective of this paper is to draw out themes from this messiness by using an analytical framework applied to diverse case studies from various geographical locations that concern different scales of governance, and that focus on a wide variety of different water dilemmas (e.g., flood, eutrophication, agricultural impacts, etc.). This approach helps us to identify spaces where there is a potential for transformation or where transformation has already taken place.

\section{The Context, Structure, Process and Outcomes of Water Governance Institutions and Organisations}

Our approach here is grounded in the precepts of an institutional and organisational perspective, which helps us appreciate different structures and processes shaping governance outcomes [25]. We define institutions as being the systems of rules, decision-making procedures, and programs that give rise to social practices, and guide interactions among the occupants of relevant roles. Institutions represent socialised ways of facilitating, or constraining, societal action-the norms (informal), the rules (formal) and the social arrangements that underpin a society [26]. Organisations, in contrast, 
are material entities that typically operate as actors in social practices. They include formalised agencies such as government bodies or NGOs that participate as stakeholders in governance contexts [26,27]. A dialectical relationship ultimately exists between organisations and institutions. By examining this dialectical relationship, a deeper understanding of how societies adapt to environmental change can be achieved. Institutional analysis can highlight the decisions that people make about their contexts and how the relationships between humans, nature and society are altered in the face of new circumstances [28]. It can also reveal the diversity of relationships and how these are perceived, maintained, challenged and re-made through time.

Examining diverse water governance processes can assist in and assess if practices can enable potential contributions to adaptive and systemic transformations and the constraints upon the emergence of 'new' arrangements. It can provide a pathway for envisaging potential governance transformations in the context of climate change [29], by asking how such changes take place [30]. As Preston et al. note, the focus on transformation 'shifts the discourse around adaptation from one focused on incremental adjustments that yield incremental benefits to one focused on system transformation' [31]. This adaptive transformation involves the fundamental alteration of different actors' perspectives on social and ecological objectives and in the manner in which they can be achieved [31]. The necessity for such transformation has increasingly been recognized in the climate change adaptation literature, as existing norms and practices are likely to be insufficient for dealing with future environmental events [32-36].

In our approach, we recognize that institutional forms are emerging and shaping water-related actions and that water and water events shape institutions and organisations in return. To see promising configurations, however, there is a need to step outside of the box of a managerial paradigm, with its specific formulations about governmental authority, sovereign territory, and universal scientific knowledge [35]. Furthermore, there is a need to understand the geography of adaptation [36,37], with a significant part of this being "what climate means for people and places and the relationship between people and places over time" [38]. In essence, there is a need for a governance approach based on reflexive decision-making, whereby adaptive outcomes are continuously monitored for promising configurations, as they can often emerge from non-linear circumstances, embodying dislocated actions, ideas and pathways [29]. This includes a focus on learning, which includes, in the context of sustainability, a range of cognitive, normative and behavioural changes in individuals, groups and organisations that promote processes and substantive improvements in environmental outcomes [39]. Thus, by considering transformative adaptation in terms of (self-reflective) learning, institutional alterations can be a genuine adaptive strategy [40-42].

Such transformative adaptive capacity approaches can therefore enhance the ability of actors (collectively and individually) to respond, to create and shape variability within socio-ecological systems $[43,44]$. As such, additional or adjusted institutional design propositions are necessary to facilitate learning processes to deal with the complexities and uncertainties related to climate change impacts. It is not a case of developing specific blueprints, but rather encouraging adaptation tuned to socially accepted features of local geography, ecology, economies and cultural beliefs and practices [45]. In this sense, the discussion here does not provide instructions for adaptation, but rather an analytical process that can be used as a vehicle for the understanding of water governance dilemmas and their potential transformations. We argue that it is in such dilemmas that innovative processes of governance can be found, not just by formally enquiring about them (i.e., evaluation) but by understanding their context, structure, process and outcomes.

\section{Methodology}

For our methodological approach, we draw upon the CSPO (context, structure, process and outcomes) framework developed by Bellamy et al. to understand the historical institutional structures and processes that cause transformations [46]. This is an approach that has some parallels with the sustainable livelihoods framework (SLF) developed by the United Kingdom's Department for 
International Development $[47,48]$, which has been used for analysing adaptive capacity in the context of climate change $[49,50]$, but it is different in that it identifies change in governance systems more broadly, rather than just focusing on livelihood outcomes. Thus CSPO provides a holistic frame to capture the institutional processes that can shape adaptive transformations.

Adaptive transformation ultimately emerges from a certain context; therefore, Context in CSPO specifically refers to the social, economic, environmental, institutional and technological influences that characterise the emerging issue, as well as the underlying policy responses and implementation processes. Structure refers to organisational and institutional arrangements, both informal relationships and more formalised rules and policy mechanisms that are involved for natural resource management across different governmental scales. Process refers to the events, activities, strategies, operations and relationships that represent the interpretation of organisational and institutional arrangements and shape the functionality of planning systems that could also drive institutional and organisational change. Finally, Outcomes refers to the outputs produced as well as the impacts realised, both anticipated and unanticipated, as a result of institutional and organisational processes [46]. The overall process is situated within a certain water dilemma (e.g., floods, eutrophication) and is the product of a specific context. Governance responses to the dilemma are then influenced by the dialectical interaction between societal structures and processes, and are conditioned by the responses and actions taken by the actors involved in the system. In employing this framework, we are particularly interested in the structure-process combinations that could be enabling transformative changes, creating a new and iterative moment of CSPO.

The case studies presented here are part of the CADWAGO project, "Climate change adaptation and water governance: reconciling food security, renewable energy and the provision of multiple ecosystem services". The project aimed to improve water governance by developing a more robust knowledge base and enhancing capacity to adapt to climate change. CADWAGO was led by the Stockholm Environment Institute (SEI) and brought together ten partners from Europe, Australasia and North America with extensive experience in climate change adaptation and water governance issues, and aimed at extending global knowledge base by sharing methods and findings to inform environmental policy-making within the European Union. The nine case studies (see Figure 1) represent water governance research projects that had been conducted by researchers across six research institutes. They were selected to represent a range of water dilemmas including those associated with: water scarcity, trans-boundary governance, flood disaster management, agricultural practices, coastal management, catchment management and eutrophication. Specifically, the case studies were:

- Baltic Sea Case Study-Focused on the Baltic Sea region, this case study explores how mainstream regulatory and market-based instruments are complemented with 'institutional measures' for stakeholder negotiation toward trans-boundary collective action in relation to the use and distribution of mineral phosphate (research led by the Stockholm Environment Institute).

- South East Queensland Floods (Australia) Case Study-Focused on the South East Queensland flood event of 2010-2011, this case study focuses on the institutional and organisational arrangements that emerged in response to the disaster, as well as the transformative path that disaster management has gone through since in the region (research led by the University of the Sunshine Coast).

- English Case Study-The impetus for this case study emerged after a legal challenge (in 2010) was launched by the UK branch of the World Wildlife Fund (WWF) and the Angling Trust against the UK Department of Environment, Food and Rural Affairs (DEFRA) for not adhering to the 2009 EU Water Framework Directive (WFD); a legal challenge that ultimately led to organisational changes (research led by the Open University).

- Integrated Coastal Management (Australia) Case Study-The focus of this case study is to explore the mechanisms by which institutional and organisational approaches can facilitate or hinder integrated coastal management (research led by the University of the Sunshine Coast). 
- Indonesian Case Study-This case study examines new 'hybrid' (coercive/non-coercive) accountability mechanisms that can enable the mobilisation of European policies on trade in palm oil and renewable energy to leverage improved water management in the palm oil industry. From an institutional perspective, this case study seeks to identify ways to overcome vertical channels of accountability (e.g., voting and lobbying) and to search for 'new' ways in which actors can influence formal processes of decision-making and action (research led by the Stockholm Environment Institute).

- Swedish Case Study-This case study looks at how existing ideas of masculinity and femininity in the Swedish County Administrative Boards (CABs) affect natural resource management (NRM) actions in marine and coastal areas. The case is interested in understanding what gendered norms look like in practice in NRM organisations in Sweden (research led by the Swedish University of Agricultural Science).

- Tunisian Case Study-Focused on an arid region in the southeast of Tunisia, this case study is focused on the link between agricultural practices and the high levels of variability that communities experience in terms of water accessibility (research led by the University of Sassari).

- Canadian Case Study-The main focus of this case study is on water scarcity, defined as water quality and quantity, in the Niagara watershed. The multi-jurisdictional complexity of governmental agencies, legislations and norms at the different levels of government, combined with an array of actors with varied interests over water draws an intricate portrait of water governance that is challenged under the conditions of climate change (research led by Brock University).

- Italian Case Study-This case study focuses on the Arborea Region, an area located in Sardinia, Italy. This region has been classified as a Nitrate Vulnerable Zone (NVZ) according to the EU "Nitrate Directive" and there are concerns about the actual quality of groundwater and wetlands in the NVZ catchment. The study looks at the integration of local and scientific knowledge to enhance better understandings of agri-environmental issues (research led by the University of Sassari).

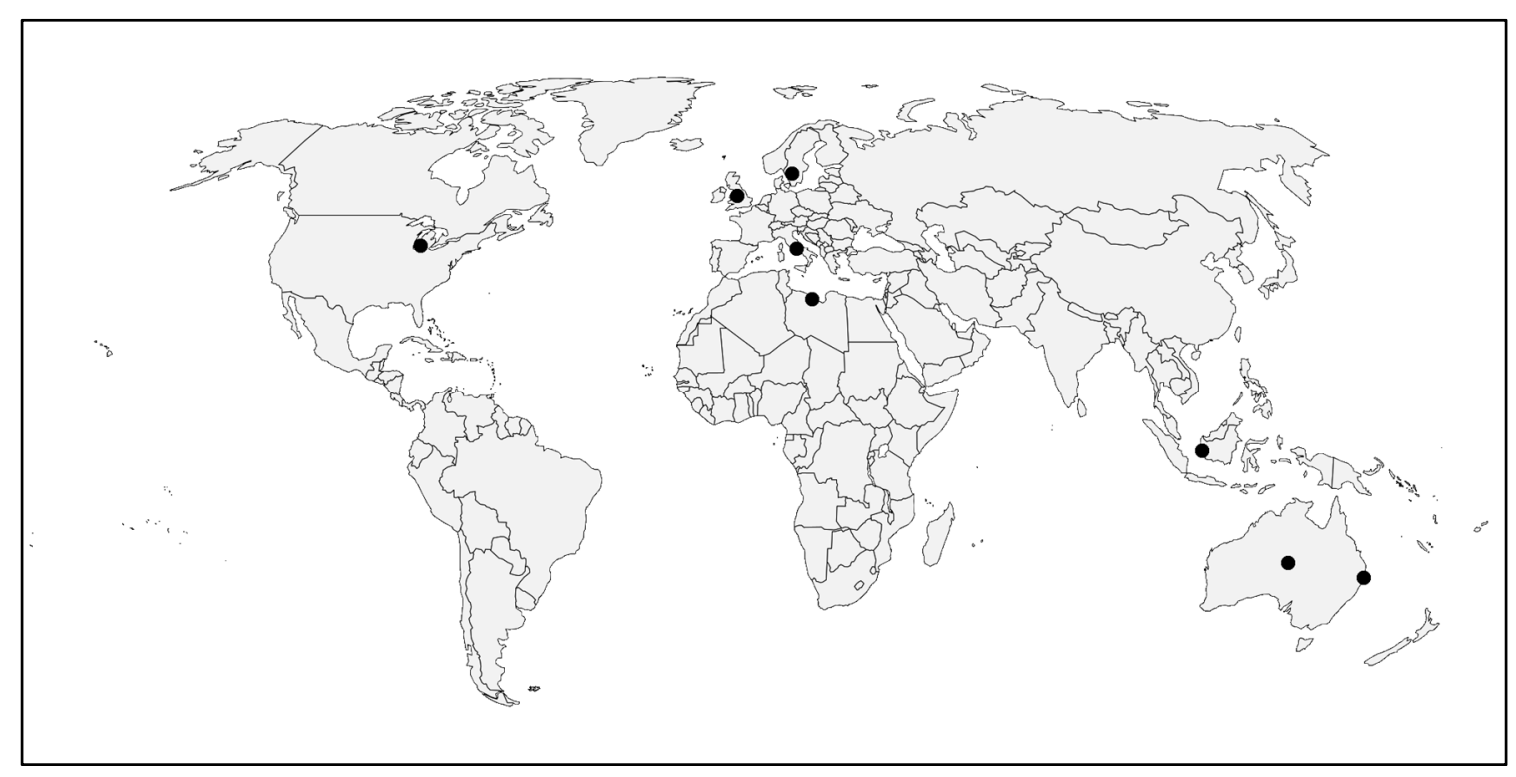

Figure 1. Locations of CADWAGO case studies.

An iterative interview process with leading researchers (key informants) in each water dilemma was conducted, as well as them providing recommendations for key pieces of policy-orientated literature. The interviews and literature provided the key data and foundation for our research 
analysis. Interview questions were structured around the different frames of CSPO. The interviews were subsequently transcribed, codified and analysed for key themes. The theme then provided the basis for the analytical discussion of the article. Case study contacts were invited to contribute to the paper after the analysis of the data, to help deepen the overall conclusions and to act as a form of 'epistemic checking' [51]. Overall, the data and approach of article is the emergence of a discussion on water governance by a diverse international collaboration of academics. This approach complements recent research that uses multiple case studies to help illuminate emerging trends and issues in global water governance and climate change [12,44,45,52,53], and contributes to the debates surrounding 'tailored frameworks' on water governance as they help in identifying transformative adaptation. In order to achieve this, the following section of the paper details the assumptions and analytical framework that we have drawn upon to analyse the nine CADWAGO case studies. This is followed by a discussion of the results and analysis, where we develop and discuss key thematic areas of water governance and their relevance for transformation.

\section{Promising Configurations in Water Governance}

Our contribution to the CSPO framework is to identify moments where incremental changes (i.e., different from transformational) are taking place and define them as such, but at the same time to identify spaces where there is a potential for transformation or where transformation has taken place. While conducting the analysis, our focus was to provide a clear contribution to current debates about water governance and climate change and explore the implications in the context of the critical social sciences (e.g., in certain sub-fields of human geography). While many topics emerged in different case studies, the themes of: democratised performance; the presence of multiple types of knowledge; the prescribing of solutions that pay attention to broader political economy issues; and the acknowledgement of socio-ecological entanglements all emerged as lynchpin thematic areas for identifying promising configurations. The presence of these themes was not equal across the case studies, rather strength of their presence varied, and the areas of weakness can be interpreted as potential barriers to realising more adaptive transformation.

\subsection{Democratised Performance}

A key attribute across a number of the case studies relates to effective participation of actors outside the public sphere- the private sector, NGOs and local communities. The English case study was exemplary of this:

“With the first round of river basin planning, 2005 to 2009, the UK Government proposed that the water governance system should have a river basin planning approach. This was pretty conventional and didn't transform the water governance agenda for practice or policy. Somewhere along the way WWF [World Wildlife Fund] and the Angling Trust got involved, and threatened a judicial review to DEFRA [Department of Environment, Food and Rural Affairs]. To avoid this situation, DEFRA agreed to introduce a more collaborative catchment-based approach ..." (English Case Study Contact 2013).

In the English, Indonesian and South East Queensland case studies, NGOs have the resources and the political space to assert themselves (i.e., substantially influence policy outcomes) in the context of their dilemmas and shape water governance scenarios in a positive manner. While, in the Tunisian case study, mechanisms were put in place to enhance the participation of local (to the water dilemma) communities, but varying degrees of success were shown mainly due to local resource limitations (human and financial). This reflects two key themes in terms of democratised performance. First, that there needs to be a critical political space that allows for non-governmental actors from multiple sectors to be able to engage with and influence the governing process $[24,53,54]$, or that someone within the system is able to identify such spaces in practice. And second, that these entities need sufficient resources (human, social, financial capital) to be able to realise and enact such potential change [54-56]. 
Time is also an important consideration for democratic participation [53]. For example, in the Italian case study, a long-term collaboration process between researchers and farmers has helped in the emergence of democratised performances, where unprompted participation has aided in identifying not only the 'needs' of farmers, but also has helped to transform farmers' understandings of the relationships between agricultural practices and associated ecological impact on water bodies (i.e., water pollution). Such changes are aligned with the need to maintain livelihoods that comply with regulatory framings and the consideration of socio-ecological impacts, while, in the South East Queensland case study, overtime capacities have shifted, allowing for the development of disaster management expertise at the local government level. Thus, an aspect to consider here is how long-term relationship processes between researchers and participants of a certain water dilemma can be effective in shaping the 'practice' of research as well as of those related with the specific dilemma.

In the agricultural science domain, the political response to negative consequences of agricultural practices on water quality (e.g., nitrate pollution of groundwater) through science-informed best practice protocols or top-down rules (e.g., the EU Nitrates Directive) were often recognized by participants as ineffective and inefficient [57] when compared with investments in long lasting processes leading to the development of hybrid knowledges [9,58]. This discussion on democratised performance has aided in the mapping and understanding of who participates where and when independently of the prescribed roles [59]. This, for a long time has been the focus of governance studies [60] and multiple categories have been created to explain them [61,62]. The thematic area we present here, however, departs from the assumption that the members of the system are already in place, emerging out of siloed prescribed job descriptions, but also that innovative arrangements may emerge out of an entanglement of understandings about what the 'other' is doing in the system. These can be seen as 'collaborative approaches,' where understandings emerged from collective interactions among scientists, managers and other stakeholders $[53,63,64]$.

Sometimes it can take a crisis to create the critical space for different forms of participation to emerge. The 2001 tragedy in the Canada town of Walkerton is an example of this: the Walkerton community had its water supply contaminated with E. coli bacteria, which in turn caused seven deaths and 2300 people to fall ill. Public panic about the drinking water spread throughout the province, forcing the government to make an in-depth inquiry into the issue [65]. What emerged out of this inquiry process was new forms of engagement between the public and government:

"The Walkerton Commission used a framework referred to as the multi-barrier approach for safe drinking water. As part of the legislation they actually went to a government led, but collaborative decision-making process. They set terms of reference of how many representatives from different sectors had to be part of the decision-making process. They nested it at the local water basin as the scale of decision-making. This represented a shift from the way we did things 10-15 years ago, we are heading towards a hybrid collaborative way of decision-making" (Canadian Case Study Contact 2013).

Shifting from a recent history of funding cutbacks for monitoring and evaluation of water quality, the Walkerton crisis provided the impetus for new legislation and a stronger regulatory framework to not only monitor water quality, but also for better integration between land use planning and watershed management [66,67].

Even though resources, skills and capacities are valued as necessary to promote adaptation and action [68], the starting point for change seems to be strongly related to the idea of letting people organise, mobilise their own arrangements to plan and take decisions. This, therefore, is an understanding of democratisation in its broadest and pluralist sense: that relevant actors are able to realise their potential within a complex system. This is not a criterion that advocates for the suppression or promotion of hierarchies, but one that understands the differences in the position of actors in the field (the arena where the dilemma is taking place) and how this determines their responsibilities [59].

Democratised performance is therefore about knowing what to do and having the tools to act accordingly. It considers collaboration and coordination as being essential in this process, but it differs 
from forced forms of participation as it also considers creating a critical space that allows for actors to create their own arrangements. Ascribed identities must be challenged for transformations to take place [69].

\subsection{Recognising Multiple Constructions of a Dilemma}

It is an axiom in contemporary critical social science to recognise, with varying ontologies [70,71], that there are multiple, often contested, social constructions of reality [72]. Knowledge is contested, as noted with the Baltic Sea case study:

"Existing policy frames are optimising a particular norm, that is they are continuously reproduced and it is based on certain assumptions that are not necessarily changing the system [...] But there are clearly different worldviews and there are different grounds for knowing what you know in the system [...] we have just basically put phosphorus into a black box and said it is an issue but it may not be deconstructed as an issue, it is more or less a problem for different stakeholders in the system. For example, nutrient enrichment related with phosphorus may not be considered as an issue to some stakeholders" (Baltic Sea Case Study Contact 2013).

Often hegemonic knowledges, shaped and developed by elite actors, are privileged in the contexts where the dilemmas occurred, constructing problems and solutions that are often incoherent or contradictory $[73,74]$. In contrast, governance arrangements where multiple (and alternative) interpretations are recognised and considered can offer a critical space for potentially innovative and nuanced responses to water dilemmas $[75,76]$. There are plenty of studies advocating for the inclusion of multiple types of knowledges, with many of them considering transdisciplinary studies as an essential component $[77,78]$. Nonetheless, how does the recognition of multiple knowledges aid in the adaptation path? This question recognises that knowledges matter for the development of ideas and innovation and that the course of bringing them to the space where discussion and decision-making takes place is part of innovative processes $[79,80]$.

In the context of the case studies, there was great variation in the acknowledgement of different knowledge constructions. For the Tunisian and Italian case studies, a trans-disciplinary approach that incorporates local knowledges and scientific perspectives has been a key component both for water- and climate-related issues $[9,81]$. This trans-disciplinarity was the original intent of the projects. The Tunisian case was based on the recognition that, at the local level, knowledge and techniques for water harvesting have been around for thousands of years, and, while still pertinent and relevant, need to be complemented by contemporary rehabilitation interventions and techniques to help realise adaptation to future climate changes. This was realised through pilot study experiments. In the Sardinian case, the intermeshing of knowledges was achieved through a long-term collaboration between farmers, policy makers and academics, where institutional constraints were identified from a number of different perspectives.

"We organised a workshop, the idea was to develop a collective reflection on the expected impacts of Climate Change on farming and develop options for adaptation. It was useful for all to learn what are the constraints at the institutional level to implement Climate Change adaptation strategies. Many of the strategies proposed by farmers and researchers were not seen by policy makers as feasible or suitable to invest specific subsidies on the agro-climatic measures, because of constraints in the way the different regulations are framed and designed or because their adoption was far from the "business as usual" way of policy implementation at local scale" (Italian Case Study Contact 2013).

In other case studies, such as the English and the Baltic Sea, there has been an increasing recognition that knowledge has been lost or marginalised, largely due to modernist managerial approaches that emerged during the 1970s and 1980s [82-84]. In both contexts, contemporary research 
approaches attempt to reverse this trend, where localised knowledge is seen as critical to realising adaptation. Overall in the case studies, there is no simple prescription in terms of how multiple knowledges might be integrated or utilised, but rather their presence and acknowledgement has helped new and innovative forms of understanding water dilemmas and responses to emerge.

The connection between the current knowledge arrangement in the context and related actions have consequences for the immediate and long-term future, this correlation is also present in the nine water dilemmas. Such notions were strongly linked to what is known about the system, something that we can call the legacy of knowledge.

The notion of nutrient enrichment involves both nitrogen and phosphorus. Previous research suggests that it was nitrogen that was the harmful component-blue-green algae-so CAP [The European Union's Common Agricultural Policy] has been nitrogen centred. Recently, science suggests that the key driver of eutrophication is phosphorous, but still the [nitrogen] legacy prevails. (Baltic Sea Case Study Contact 2013).

The notion of legacy includes the conceptualisation of the dilemma as an issue (the social construction), the institutionalisation of it, and the praxis. Legacy permeates CSPO and it could 'stay' in the system as long as the institutional arrangements put in place allow it to do so. In the case of the Baltic Sea case study, the response to the issue could be to change the EU agricultural policy to include phosphorus, but that would reproduce issues of the Structure-Process relationship (i.e., incremental change). Legacy is also reflected in methodologies-scientific ones-mainly used to gather data and build instruments to define a certain dilemma (e.g., ocean eutrophication). The South East Queensland Case Study is an example of this: historically engineering approaches have been privileged for disaster mitigation work and while there are shifts towards more social-focused approaches, the engineering one still maintains a strong influence $[85,86]$.

From a CSPO perspective, promising configurations, when taking place, will do so in the Structure-Process relationship. Hegemonic knowledge, and the traces that the legacy knowledge and practice can leave are thus key considerations [87-92]. This is not just about the creation of a conceptual space for hybrid knowledge, but also a space where hegemonic ideas and practices could be successfully deconstructed, challenged and hence transformed-a new context.

\subsection{Framing the Dilemma Politically}

Political aspects embedded in the nine water dilemmas include dimensions of social justice, gender equality, knowledge integration, social class and livelihoods. The political also relates to the previous theme, as politics influences how different actors construct and frame dilemmas. Indeed, in this vein, there has been a tendency to propose solutions about water dilemmas that favour programs where 'green marketization' is an important component (i.e., payment for hydrological environmental services). This is largely due to the influence of a neoliberal ideology across all aspects of society, where the need to transform water into an economic good to ensure its security has become increasingly hegemonic in water governance policies [93]. Thus, market-based approaches have become dominant mechanisms for addressing water dilemmas and other environmental issues [94]. Such approaches, however, can implicitly deny the political dimensions of water, abstracting it from local, social, cultural, religious, and ecological contexts [95]. Thus, even though some policy programs have been successful in ameliorating environmental dilemmas (e.g., reducing the pollution of downstream water bodies), in the context of climate change, agreements beyond economic transactions will almost certainly be necessary.

This paper does not argue against the use of market-based mechanisms in water governance per se, but suggests they should emerge through a contested politicised process, rather than being presented as axiomatic green-economy solutions. As critics of 'green marketisation' have noted, markets are powerful mediums for producing outcomes and therefore will always play a role, nevertheless they should not supplant the decision-making of political arenas and local communities $[96,97]$. 
Environmental justice —rather than just environmental management or conservation—provides a conceptual lens (and a normative project) to challenge the dominance of market-based processes. This is an approach centred on social justice, and builds on the premise that the fights for human rights and environment are inseparable [94]. It is well argued that environmental issues and conflicts are not merely environmental, but rather need to be contextualised in broader social processes [98-100]. Environmental justice analyses, therefore, tend to have an emphasis on revealing "winners and losers, hidden costs, and the differential power that produce social and environmental outcomes" [100], also see [101]. Solving environmental issues, thus, is recognised as being a highly political process. The Sardinian case study is a good example of this, as the payment for environmental services scheme has been put in place for farmers to improve agricultural practices. The cost of the 'improvement,' however, was only affordable to a limited group of people, reinforcing existent inequalities and social exclusion (Italian Case Study Contact, 2013).

This can also be seen in the Indonesia case study, in the context of palm oil being imported into the EU to help its countries comply with the EU's renewable energy directive. The companies importing palm oil do not have a legal responsibility to mitigate the negative impacts on water resources overseas (e.g., Indonesia, the Philippines). Voluntary mechanisms, like the Roundtable on Sustainable Palm Oil (RSPO), exist, but in the contractual relationship between the buyer and the producer there is a lack of clarity about how to deal with the environmental outcomes of palm oil production:

When it comes to private civil law, it is private companies that have a duty of care towards society, but what does that duty mean? ... You have to have a monitoring authority at the European level, not to monitor what Indonesians are doing but to monitor what European actors are doing in Indonesia. But that's a political question ..., to what extent can the EU regulate what a European citizen or a legal entity is doing in Indonesia in terms of business abuse? (Indonesian Case Study Contact 2013).

Palm oil farmers have exacerbated extractive practices in their geographical locality by being part of the biofuel production process of the EU [102]. In the context of climate change, countries with the resources and political will to implement mitigation practices may be exporting related environmental and social issues to other contexts (e.g., social inequalities, corruption). CSPO has helped to identify this by understanding the political capital existent in the context and the investment placed in the organisational and institutional structures.

\subsection{Socio-Ecological Entanglements Acknowledged}

[The catchment approach] was a real shift in the way policymakers are thinking about water governance ... that is a real keepsake and the language as a result is changing ... you can hear them talking about learning, you can hear them talking about catchments in a way which suggests that they understand catchments as not just a biophysical entity but a socio-ecological entity. (England Case Study Contact 2013).

The conceptualisation of nature as something separate from society has been challenged in recent social science research, with arguments focusing on the need for a nuanced understanding of dynamic socio-natural systems $[98,103]$. In the context of water, recent geographical scholarship has used the notion of the 'hydrosocial cycle' to highlight how water is moderated by social, political, economic, and cultural relations and that these relations are, in turn, influenced by the materiality and physicality of water $[59,95,104-107]$. Siloed understandings of the non-human world have influenced our managerial practices $[108,109]$. It is implicitly assumed within the hydrosocial cycle approach that good water governance would be looking to an integrated socio-ecological system rather than simply $\mathrm{H}_{2} \mathrm{O}$ as a material entity [107].

Organisational epistemologies and practices (i.e., structures and processes) in most of the nine water dilemmas were backed up by an understanding of a separation between the human and natural world. In the English case study, however, it was shown that the entanglement of 
socio-ecological systems was acknowledged and enacted through the establishment of catchment authorities. Learning-reflective learning-was an essential component of the process, something that CSPO supports. The governing innovation, or its potential, then is found here, in the reframing of the more-than-human as a socio-ecological system. The role of the social sciences in this transformational process seems to be critical to help breakdown the divide. The Queensland Flood case study also showed some potential in this regard. While historically there has been a focus on disasters being seen as 'natural disasters' and thereby being mitigated via engineered responses, recent changes in Queensland's disaster governance indicate a nascent paradigm shift, where social approaches (e.g., addressing social vulnerability) to disasters are becoming more prominent $[85,110]$.

The final consideration is that the socio-ecological divide may be identified in the context of CSPO, but its enactment would have ramifications through the structure (formalised divisions of environmental management practices) and process (siloed practices organised through departmental jurisdictions) relations.

\section{Conclusions}

A central challenge of global water governance is to find ways to address transnational socioecological controversies in a socially just and ecologically effective manner [14]. Water governance dilemmas are multi-faceted and constantly changing, and therefore a flexible analytical apparatus is needed to appreciate emerging themes and enablers for positive change. In this paper, we utilised and built upon the CSPO framework [46] to analyse nine water governance case studies. While the case studies were diverse in terms of their geographies (i.e., Africa, Australia, Europe, North America and Asia), scales (i.e., local dilemmas to trans-national issues) and specific water dilemmas (e.g., flooding, pollution and agriculture), they help to illustrate some of the underlying perspectives and implementations that underpin promising configurations in water governance, aiding our understanding of what innovative arrangements might help to promote more adaptive forms of transformation. For one, it is critical to recognise that water issues are inherently political, and therefore solutions will not emerge with neat technological or economic panaceas, but rather paying attention to messy political dynamics. Water dilemmas are products of complex socio-ecological entanglements, and recognition of this means that our analytical focus is not just on an 'external' Nature that should be managed; but rather on reshaping broader socio-ecological contexts. This is why forms of democratised performance are necessary. There needs to be a critical space that allows for actors' actions to help facilitate important forms of collaboration and coordination that allow for transformations to take place. Part of this process is a recognition of epistemological pluralism, meaning that there are multiple ways water dilemmas can be constructed and understood, and the objective should not be about establishing the correct construction (if such a thing exists), but rather understanding that the responses need to be crafted with an appreciation of different perspectives. Creative and innovative responses often emerged in the context of such hybridised knowledge.

Acknowledgments: The research for this paper is a part of the "CADWAGO: Climate change adaptation and water governance-reconciling food security, renewable energy and the provision of multiple ecosystem services" project funded as part of the "Europe and Global Challenges programme" by Compagnia di San Paolo, VolkswagenStiftung and Riksbankens Jubileumsfond. We would also like to acknowledge the valuable critical feedback provided by three anonymous reviewers.

Author Contributions: Maria de Lourdes Melo Zurita, Dana C. Thomsen, Neil J. Holbrook, Timothy F. Smith and Anna Lyth conceived the paper; Timothy F. Smith designed its methodological approach (CSPO). Maria de Lourdes Melo Zurita analysed the data. Maria de Lourdes Melo Zurita was the paper's lead author, with detailed writing input provided by Dana C. Thomsen, Neil J. Holbrook and Paul G. Munro. Annemarieke de Bruin, Giovanna Seddaiu, Pier Paolo Roggero, Julia Baird, Ryan Plummer, Ryan Bullock, Kevin Collins and Neil Powell contributed towards developing the paper's final analysis and discussion.

Conflicts of Interest: The authors declare no conflict of interest. 


\section{References}

1. Perkins, S.E.; Pitman, A.J.; Holbrook, N.J.; McAneney, J. Evaluation of the AR4 climate models simulated daily maximum temperature, minimum temperature, and precipitation over Australia using probability density functions. J. Clim. 2007, 20, 4356-4376. [CrossRef]

2. Bates, B.; Kundzewicz, Z.W.; Wu, S.; Palutikof, J. Climate Change and Water IPCC; Technical Paper VI; Intergovernmental Panel on Climate Change Secretariat: Geneva, Switzerland, 2008.

3. Barnett, J. Security and climate change. Glob. Environ. Chang. 2003, 13, 7-17. [CrossRef]

4. Barnett, J.; Adger, W.N. Climate change, human security and violent conflict. Polit. Geogr. 2007, 26, 639-655. [CrossRef]

5. Hanjra, M.A.; Qureshi, M.E. Global water crisis and future food security in an era of climate change. Food Policy 2010, 35, 365-377. [CrossRef]

6. McMichael, A.J.; Woodruff, R.E.; Hales, S. Climate change and human health: Present and future risks. Lancet 2006, 367, 859-869. [CrossRef]

7. Patz, J.A.; Campbell-Lendrum, D.; Holloway, T.; Foley, J.A. Impact of regional climate change on human health. Nature 2005, 438, 310-317. [CrossRef] [PubMed]

8. Wiltshire, A.J.; Kay, G.; Gornall, J.L.; Betts, R.A. The Impact of Climate, $\mathrm{CO}_{2}$ and Population on Regional Food and Water Resources in the 2050s. Sustainability 2013, 5, 2129-2151. [CrossRef]

9. Dell'Angelo, J.; Rulli, M.C.; D'Ordorico, P. The global water grabbing syndrome. Ecol. Econ. 2018, 143, $276-285$. [CrossRef]

10. Godden, L.; Ison, R.I.; Wallis, P.J. Editorial: Water governance in a climate change world: Appraising systemic and adaptive effectiveness. Water Resour. Manag. 2011, 25, 3971-3976. [CrossRef]

11. Conway, D. Securing Water in a Changing Climate. In Water Security: Principles, Perspectives and Practices; Lankford, B., Bakker, K., Zeitoun, M., Conway, D., Eds.; Earthscan: London, UK, 2013; pp. 80-100.

12. Huntjens, P.; Pahl-Wostl, C.; Rihoux, B.; Schlüter, M.; Flachner, Z.; Neto, S.; Nabide Kiti, I. Adaptive water management and policy learning in a changing climate: A formal comparative analysis of eight water management regimes in Europe, Africa and Asia. Environ. Policy Gov. 2011, 21, 145-163. [CrossRef]

13. Huitema, D.; Mostert, E.; Egas, W.; Moellenkamp, S.; Pahl-Wostl, C.; Yalcin, R. Adaptive water governance: Assessing the institutional prescritions of adaptive (co-)management from a governance perspective and defining a research agenda. Ecol. Soc. 2009, 14, 26. [CrossRef]

14. Conca, K. Rethinking Authority, Territory and Knowledge: Transational socio-ecological controversies and global environmental governance. In The Crisis of Global Environmental Governance: Towards a New Political Economy of Sustainability; Park, J., Conca, K., Finger, M., Eds.; Routledge: London, UK, 2008; pp. $193-207$.

15. Griggs, D.; Stafford-Smith, M.; Gaffney, O.; Rockström, J.; Öhman, M.C.; Shyamsundar, P.; Noble, I. Policy: Sustainable development goals for people and planet. Nature 2013, 495, 305-307. [CrossRef] [PubMed]

16. Pahl-Wostl, C.; Gupta, J.; Petry, D. Governance and the global water system: A theoretical exploration. Glob. Gov. A Rev. Multilater. Int. Organ. 2008, 14, 419-435.

17. Pahl-Wostl, C.; Holtz, G.; Kastens, B.; Knieper, C. Analyzing complex water governance regimes: The management and transition framework. Environ. Sci. Policy 2010, 13, 571-581. [CrossRef]

18. Bierman, F.; Pattberg, P. Global Environmental Governance Revisited. In Global Environmental Governance Reconsidered; Bierman, F., Pattberg, P., Eds.; The MIT Press: Cambridge, MA, USA, 2012; pp. 1-24.

19. Armitage, D.; de Loe, R.; Plummer, R. Environmental governance and its implications for conservation practice. Conserv. Lett. 2012, 5, 245-255. [CrossRef]

20. Young, O.R.; Berkout, F.; Gallopin, G.C.; Janessen, M.A.; Ostron, E.; Van der Leeuw, S. The globalization of socio-ecological systems: An agenda for scientific research. Glob. Environ. Chang. 2006, 16, $304-316$. [CrossRef]

21. Steyaert, P.; Jiggins, J. Governance of complex environmental situations through social learning: Asynthesis of SLIM's lessons for research, policy and practice. Environ. Sci. Policy 2007, 10, 575-586. [CrossRef]

22. Franks, T.; Cleaver, F. Water Governance and poverty: A framework for analysis. Prog. Dev. Stud. 2007, 7, 291-306. [CrossRef]

23. Jordan, A.L.; Huitema, D.; Hilden, M.; Van Asselt, H.; Rayner, T.J.; Schoenefeld, J.J.; Tosun, J.; Forster, J.; Boasson, E.L. Emergence of polycentric climate governance and its future prospects. Nat. Clim. Chang. 2015, 5, 977-982. [CrossRef] 
24. Najam, A.; Christopoulou, I.; Moomaw, W.R. The emergent "system" of global environmental governance. Glob. Environ. Polit. 2004, 4, 23-35. [CrossRef]

25. Finger, M. Which Governance for Sustainable Development? An organisation and institutional perspective. In The Crisis of Global Environmental Governance: Towards a New Political Economy of Sustainability; Park, J., Conca, K., Finger, M., Eds.; Routledge: London, UK, 2008; pp. 34-57.

26. Young, O.R. The Institutional Dimensions of Environmental Change: Fit, Interplay, and Scale; Massachusetts Institute of Technology Press: Cambridge, MA, USA, 2002.

27. Klooster, D. Toward Adaptive Community Forest Management: Integrating Local Forest Knowledge with Scientific Forestry. Econ. Geogr. 2002, 78, 43-70. [CrossRef]

28. Cleaver, F. Development through Bricolage: Rethinking Institutions for Natural Resource Management; Earthscan: Oxon, UK, 2012.

29. Pelling, M.; O’Brien, K.; Matyas, D. Adaptation and transformation. Clim. Chang. 2015, 133, 113-127. [CrossRef]

30. O'Brien, K. Global environmental change II From adaptation to deliberate transformation. Prog. Hum. Geogr. 2012, 36, 667-676. [CrossRef]

31. Preston, B.L.; Dow, K.; Berkhout, F. The climate adaption frontier. Sustainability 2013, 5, 1011-1035. [CrossRef]

32. Jacobson, C.; Hughey, K.F.D.; Lynch, A.J.J.; Nursey-Bray, M.; O'Connell, M.; Munro, P.G.; Vella, K.; Whiley, D.; Dovers, S.; Carter, R.W. Twenty years of pacifying responses to environmental management. Australas. J. Environ. Manag. 2014, 21, 143-174. [CrossRef]

33. Nalau, J.; Handmer, J. When is transformation a viable policy alternative? Environ. Sci. Policy 2015, 54, $349-356$. [CrossRef]

34. O'Neill, S.J.; Handmer, J. Responding to bushfire risk: The need for transformative adaptation. Environ. Res. Lett. 2012, 7, 14-18. [CrossRef]

35. Conca, K. Governing Water: Contentious Transnational Politics and Global Institution Building; Massachusetts Institute of Technology Press: Cambridge, MA, USA, 2006.

36. Adger, W.N.; Arnell, N.W.; Tompkins, E.L. Successful adaptation to climate change across scales. Glob. Environ. Chang. 2005, 15, 77-86. [CrossRef]

37. Lyth, A.; Harwood, A.; AHobday, A.J.; McDonald, J. Place influences in framing and understanding climate change adaptation challenges. Local Environ. 2016, 21, 730-751. [CrossRef]

38. Hulme, M. Geographical work at the boundaries of climate change. Trans. Inst. Br. Geogr. 2008, 33, 5-11. [CrossRef]

39. Armitage, D.; Dzyundzyak, A.; Baird, J.; Bodin, O.; Plummer, R.; Schultz, L. An Approach to Assess Learning Conditions, Effects and Outcomes in Environmental Governance. Environ. Policy Gov. 2017. [CrossRef]

40. Baird, J.; Plummer, R.; Haug, C.; Huitema, D. Learning effects of interactive decision-making processes for climate change adaptation. Glob. Environ. Chang. 2014, 27, 51-63. [CrossRef]

41. Blackmore, C.; Cerf, M.; Ison, R.I.; Paine, M. The role of action-orientated learning theories for change in agriculture and rural networks. In Farming Systems Research into the 21st Century: The New Dynamic; Darnhofer, I., Gibbon, D., Dedieu, B., Eds.; Springer: Berlin, Germany, 2012; pp. 159-178.

42. Serrao-Neumann, S.; Davidson, J.L.; Baldwin, C.A.; Dedekorkut-Howes, A.; Ellison, J.C.; Holbrook, N.J.; Howes, M.; Jacobson, C.; Morgan, E.A. Marine governance to avoid tipping points: Can we adapt the adaptability envelope? Mar. Policy 2016, 65, 56-67. [CrossRef]

43. Hill, M.; Engle, N.L. Adaptive capacity: Tensions across scales. Environ. Policy Gov. 2013, 23, 177-192. [CrossRef]

44. Hubert, B.; Ison, R.I.; Sriskandarajah, N.; Blackmore, C.; Cerf, M.; Avelange, I.; Steyaert, P. Learning in European agricultural and rural networks: Building a systemic research agenda. In Farming Systems Research into the 21st Century: The New Dynamic; Darnhofer, I., Gibbon, D., Dedieu, B., Eds.; Springer: Berlin, Germany, 2012; pp. 179-200.

45. Huntjens, P.; Lebel, L.; Pahl-Wostl, C.; Camkin, J.; Schulze, R.; Kranz, N. Institutional design propositions for the governance of adaptation to climate change in the water sector. Glob. Environ. Chang. 2012, 22, 67-81. [CrossRef]

46. Bellamy, J.; Smith, T.; Taylor, B.; Walker, M.; McDonald, G.; Jones, J.; Pero, L. Criteria and Methods for Monitoring and Evaluating Health Regional Planning Arrangements; Tropical Savannas Cooperative Research Centre (CRC): Darwin, Australia, 2005. 
47. Carney, D. Sustainable Livelihoods Approaches: Progress and Possibilities for Change. Available online: http:/ / www.eldis.org/vfile/upload/1/document/0812/SLA_Progress.pdf (accessed on 22 December 2017).

48. Scoones, I. Sustainable Rural Livelihoods: A Framework for Analysis; IDS Working Paper; Institute of Development Studies: Brighton, UK, 1998.

49. Plummer, R. The adaptive co-management process: An initial synthesis of representative models and influential variables. Ecol. Soc. 2009, 14, 24. [CrossRef]

50. Plummer, R.; Armitage, D. A resilience-based framework for evaluating adaptive co-management: Linking ecology, economics and society in a complex world. Ecol. Econ. 2007, 61, 62-74. [CrossRef]

51. Demeritt, D. The promises of participation in science and political ecology. In The Routledge Handbook of Political Ecology; Perreault, T., Bridge, G., McCarthy, J., Eds.; Routledge: London, UK, 2015; pp. 224-334.

52. Biswas, A.K.; Tortajada, C. Future water governance: Problems and perspectives. Water Resour. Dev. 2010, 26, 129-139. [CrossRef]

53. Colvin, J.; Blackmore, C.; Chimbuya, S.; Collins, K.; Dent, M.; Goss, J.; Ison, R.; Roggero, P.P.; Seddaiu, G. In search of systemic innovation for sustainable development: A design praxis emerging from a decade of social learning inquiry. Res. Policy 2014, 43, 760-771. [CrossRef]

54. Ansell, C.; Gash, A. Collaborative governance in theory and practice. J. Public Adm. Res. Theory 2008, 18, 543-571. [CrossRef]

55. Pahl-Wostl, C.; Craps, M.; Dewulf, A.; Mostert, E.; Tabara, D.; Taillieu, T. Social Learning and water resources management. Ecol. Soc. 2007, 12, 5. [CrossRef]

56. Pahl-Wostl, C. Water Policy-From Panaceas Towards Embracing Complexity. In Water Governance in the Face of Global Change; Springer International Publishing: Berlin, Germany, 2015; pp. 11-24.

57. Allan, C.; Nguyen, T.P.L.; Seddaiu, G.; Wilson, B.; Roggero, P.P. Integrating local knowledge with experimental research: Case studies on managing cropping systems in Italy and Australia. Ital. J. Agron. 2013, 8, 15. [CrossRef]

58. Nguyen, T.P.L.; Seddaiu, G.; Roggero, P.P. Hybrid knowledge for understanding complex agri-environmental issues: Nitrate pollution in Italy. Int. J. Agric. Sustain. 2014, 12, 164-182. [CrossRef]

59. Melo Zurita, M.; Cook, B.; March, A.; Harms, L. Towards New Disaster Governance: Subsidiarity as a critical tool. Environ. Policy Gov. 2015, 25, 386-398. [CrossRef]

60. Marks, G. An actor-centred approach to multi-level governance. Reg. Fed. Stud. 1996, 6, 20-38. [CrossRef]

61. Cornwall, A. Unpacking 'Participation': Models, meanings and practices. Community Dev. J. 2008, 43, $269-283$. [CrossRef]

62. Reed, M.S. Stakeholder participation for environmental management: A literature review. Biol. Conserv. 2008, 141, 2417-2431. [CrossRef]

63. Taylor, B.; de Loe, R.; Bjornlund, H. Evaluating knowledge production in collaborative water governance. Water Altern. 2013, 6, 42.

64. Brisbois, M.C.; de Loe, R.C. Power in collaborative approaches to governance for water: A systematic review. Soc. Nat. Resour. 2016, 29, 775-790. [CrossRef]

65. Schwartz, R.; McConnell, A. Do crises help remedy regulatory failure? A comparative study of the Walkerton water and Jerusalem banquet hall disasters. Can. Public Adm. 2009, 52, 91-112. [CrossRef]

66. De Loe, R.; Kreutzwiser, R. Challenging the Status Quo: The evolution of water governance in Canada. In Eau Canada: The Future of Canadian Water Governance; Bakker, K., Ed.; University of BC Press: Vancouver, BC, Canada, 2007; pp. 85-103.

67. Plummer, R.; de Grosbois, D.; de Loe, R.; Velaniskis, J. Probing the integration of land use and watershed planning in a shifting governance regime. Water Resour. Res. 2011, 47. [CrossRef]

68. Moser, S.C.; Ekstrom, J.A. A framework to diagnose barriers to climate change adaptation. Proc. Natl. Acad. Sci. USA 2010, 107, 22026-22031. [CrossRef] [PubMed]

69. Bottrell, D. Understanding 'marginal' perspectives towards a social theory of resilience. Qual. Soc. Work 2009, 8, 321-339. [CrossRef]

70. Demeritt, D. Science, Social Constructivism and Nature. In Remaking Reality: Nature at the New Millennium; Braun, B., Castree, N., Eds.; Routledge: New York, NY, USA, 1998; pp. 173-193.

71. Demeritt, D. Being constructive about nature. In Social Nature: Theory Practice and Politics; Castree, N., Braun, B., Eds.; Blackwell: Oxford, UK, 2001; pp. 22-40. 
72. De Rjike, K.; Munro, P.; Zurita, M.D.L.M. The Great Artesian Basin: A contested resource environment of subterranean water and coal seam gas in Australia. Soc. Nat. Resour. 2016, 29, 696-710. [CrossRef]

73. Munro, P.G. Deforestation: Constructing Problems and Solutions on Sierra Leone's Freetown Peninsula. J. Polit. Ecol. 2009, 16, 104-124.

74. Bullock, R. Mill town identity crisis: Reframing the culture of forest resource dependence in single industry towns. In Social Transformation in Rural Canada: New Insights into Community, Cultures and Collective Action; Parkins, J., Reed, M., Eds.; University of British Columbia Press: Vancouver, BC, Canada, 2013; pp. 269-290.

75. Berkes, F. Evolution of co-management: Role of knowledge generation, bridging organizations and social learning. J. Environ. Manag. 2009, 90, 1692-1702. [CrossRef] [PubMed]

76. Plummer, R.; Armitage, D.; de Loe, R. Adaptive comanagement and its relationship to environmental governance. Ecol. Soc. 2013, 18, 21. [CrossRef]

77. Polk, M.; Knutsson, P. Participation, value rationality and mutual learning in transdisciplinary knowledge production for sustainable development. Environ. Educ. Res. 2008, 14, 643-653. [CrossRef]

78. Pregernig, M. Transdisciplinarity viewed from afar: Science-policy assessments as forums for the creation of transdisciplinary knowledge. Sci. Public Policy 2006, 33, 445-455. [CrossRef]

79. Kofinas, G.P.; Herman, S.J.; Meek, C. Novel problems require novel solutions: Innovation as an outcome of adaptive co-management. In Adaptive Co-Management: Collaboration, Learning and Multi-Level Governance; Armitage, D., Berkes, F., Doubleday, N., Eds.; University of British Columbia Press: Vancouver, BC, Canada, 2007; pp. 249-267.

80. Berkes, F.; Armitage, D.; Doubleday, N. Synthesis: Adapting, innovating, evolving. In Adaptive Co-Management: Collaboration, Learning and Multi-Level Governance; Armitage, D., Berkes, F., Doubleday, N., Eds.; University of British Columbia Press: Vancouver, BC, Canada, 2007; pp. 308-327.

81. Nguyen, T.P.L.; Seddaiu, G.; Virdis, S.G.P.; Tidore, C.; Pasqui, M.; Roggero, P.P. Perceiving to learn or learning to perceive? Understanding farmers' perceptions and adaptation to climate uncertainties. Agric. Syst. 2016, 143, 205-216. [CrossRef]

82. Collins, K.B.; Ison, R.L. Trusting emergence: Some experience of learning about integrated catchment science with the Environmental Agency of England and Wales. Water Resour. Manag. 2010, 24, 669-688. [CrossRef]

83. Collins, K.; Blackmore, C.; Morris, D.; Watson, D. A systemic approach to managing multiple perspectives and stakeholdingin water catchments: Some findings from three UK case studies. Environ. Sci. Policy 2007, 10, 564-574. [CrossRef]

84. Larsen, R.L.; Powell, N. Making Sense of Accountability in Baltic Agro-Environmental Governance: The Case of Denmark's Green Growth Strategy. Soc. Environ. Account. J. 2013, 33, 71-90. [CrossRef]

85. Plummer, R.; Baird, J.; Bullock, R.; Dzyundzyak, A.; Dupont, D.; Gerger Swartling, A.; Johannessen, A.; Huitema, D.; Lyth, A.; Melo Zurita, M.; et al. Stakeholder Insights into Flood Governance: An International Mutiple Case Study of Flood Prone Areas. Environ. Policy Gov. 2008, forthcoming.

86. Plummer, R.; Renzetti, S.; Bullock, R.; Melo Zurita, M.D.L.; Baird, J.; Dupont, D.; Smith, T.; Thomsen, D. The Roles of Capitals in Building Capacity to Address Urban Flooding in the shift to a new water management approach. Environ. Plan. C 2017. [CrossRef]

87. Bryant, R.L. Power, knowledge and political ecology in the third word: A review. Prog. Phys. Geogr. 1998, 22, 79-94. [CrossRef]

88. Ribot, J.C. A history of Fear: Imagining deforestation in the West African dryland forests. Glob. Ecol. Biogeogr. 1999, 8, 291-300. [CrossRef]

89. Sivaramakrishnan, K. Modern Forests: Statemaking and Environmental Change in Colonial Eastern India; Stanford University Press: Stanford, CA, USA, 1999.

90. Fairhead, J.; Leach, M. Reframing Deforestation: Global Analyses and Local Realities: Studies in West Africa; Routledge: London, UK, 1998.

91. Robbins, P. The practical politics of knowing: State environmental knowledge and local political economy. Econ. Geogr. 2000, 76, 126-144. [CrossRef]

92. Munro, P.G.; Hiemstra-can der Horst, G. Conserving exploitation? A political ecology of forestry policy in Sierra Leone. Australas. Rev. Afr. Stud. 2011, 32, 59-78.

93. Swyngedouw, E.; Kaika, M.; Castro, E. Urban water: A political-ecology perspective. Built Environ. 2002, $28,124-137$. 
94. Anguelovski, I.; Martínez-Alier, J. The 'Environmentalism of the Poor' revisited: Territory and place in disconnected glocal struggles. Ecol. Econ. 2014, 102, 167-176. [CrossRef]

95. Linton, J. Modern water and its discontents: A history of hydrosocial renewal. Wiley Interdiscip. Rev. Water 2014, 1, 111-120. [CrossRef]

96. Hamilton, C. Foundations of Ecological Economics. In Human Ecology, Human Economy: Ideas for an Ecologically Sustainable Future; Diesendorf, M., Hamilton, C., Eds.; Allen and Unwin: Sydney, Australia, 1997; pp. 35-60.

97. Gomez-Baggethun, E.; Muradian, R. In markets we trust? Setting the boundaries of market-based instruments in ecosystems services governance. Ecol. Econ. 2015, 117, 217-224. [CrossRef]

98. Castree, N.; Braun, B. (Eds.) Social Nature: Theory, Practice, and Politics; Blackwell: Oxford, UK, 2001.

99. Schlosberg, D. Defining Environmental Justice: Theories, Movements, and Nature; Oxford University Press: Oxford, UK, 2009.

100. Robbins, P. Political Ecology: A Critical Introduction, 2nd ed.; John Wiley \& Sons: Hoboken, NJ, USA, 2012.

101. Munro, P.G.; van der Horst, G.; Healy, S. Energy Justice for All? Rethinking Sustainable Development Goal 7 through struggles over traditional energy practices in Sierra Leone. Energy Policy 2017, 105, 635-641. [CrossRef]

102. Obidzinski, K.; Andriani, R.; Komarudin, H.; Andrianto, A. Environmental and social impacts of oil palm plantations and their implications for biofuel production in Indonesia. Ecol. Soc. 2012, 17, 25. [CrossRef]

103. Plumwood, V. Decolonisation Relationships with Nature. PAN Philos. Act. Nat. 2002, 2, 7-30.

104. Barnes, J. Mixing waters: The reuse of agricultural drainage water in Egypt. Geoforum 2014, 57, 181-191. [CrossRef]

105. Budds, J.; Linton, J.; McDonnell, R. The hydrosocial cycle. Geoforum 2014, 57, 167-169. [CrossRef]

106. Swyngedouw, E. The city as a hybrid: On nature, society and cyborg urbanization. Capital. Nat. Soc. 1996, 7, 65-80. [CrossRef]

107. Melo Zurita, M.; Thomsen, D.; Smith, T.; Lyth, A.; Preston, B.L.; Baum, S. Reframing water: Contesting $\mathrm{H}_{2} \mathrm{O}$ within the European Union. Geoforum 2015, 65, 170-178. [CrossRef]

108. Lele, S.; Norgaard, R.B. Practicing interdisciplinarity. BioScience 2005, 55, 967-975. [CrossRef]

109. Miller, T.; Baird, T.; Littlefield, C.; Kofinas, G.; Chaping, F.S., III; Redman, C. Epistemological pluralism: Reorganizing interdisciplinary research. Ecol. Soc. 2008, 13, 46. [CrossRef]

110. Melo Zurita, M.; Cook, B.; Thomsen, D.; Munro, P.G.; Smith, T.F.; Gallina, J. Living with Disasters: Social Capital for Disaster Governance. Disasters 2017. [CrossRef] [PubMed] 